\title{
Influence of Tannery Effluents on Morphological Characters of Ipomoea pes-caprae (L.) Sweet and Clerodendron inerme (L.) Gaertn.
}

\section{A. Venkatesan}

Department of Botany, Annamalai University, Annamalainagar-608 002, Tamilnadu, India; venkatesan2k@yahoo.com

\section{Nat. Env. \& Poll. Tech.} Website: www.neptjournal.com

Received: 16-07-2019 Accepted: 29-08-2019

\section{Key Words:}

Tannery effluent; Halophytes; Ipomoea pes-caprae; Clerodendron inerme

\begin{abstract}
Tannery industry is common in many parts of the world, which is polluting groundwater ecosystems and producing major heavy metals and sodium chloride. The present study is aimed at some morphological characters in phytoremediation of heavy metals and ions from tannery effluents by using halophytic species such as Ipomoea pes-caprae and Clerodendron inerme. The morphological characters were analysed at an interval of $30,60,90$ and 120 days. The results indicated that all the morphological characters were increased with an increasing concentration of tannery effluents and no injury symptoms in growth condition. It may be concluded that these halophytic species are potentially suitable for phytoremediation of heavy metals from the tannery effluent contaminated soils, which will reclaim the soil for further use as crop cultivation or crop improvement.
\end{abstract}

\section{INTRODUCTION}

Soil and water pollution by toxic heavy metals is a major environmental concern worldwide. Heavy metals are extremely toxic and present in our immediate environment. Irrespective of the origin of the metals in soils, excessive levels of many metals can result in the quality degradation, crop yield reduction, and poor quality of agricultural products (Long et al. 2002). Naturally occurring heavy metals have a great adsorption capacity in soil and are thus not readily available for living organisms. The bonding energy between heavy metals and soil is very high compared to that with anthropogenic sources. Heavy metals from anthropogenic source typically have a high bioavailability due to their soluble and mobile relative forms (Dixit et al. 2015).

Bioremediation is a process that uses microorganisms on their enzymes to promote degradation and/or removal of contaminants from the environment (Perpetuo et al. 2011). One of these strategies, biostimulation, involves promoting the growth of microorganisms at the contaminated site in order to introduce $\mathrm{pH}$-correction substances, nutrients surfactants and oxygen. Another strategy, bioaugmentation or bioaddition is the addition of microbial populations indigenous alien or genetically modified organisms in places where there is an insufficient of indigenous microorganisms with ecophysiologically characteristics compatible with the habitat conditions that are conducive for the promotion of bioremediation ( $\mathrm{Li} \& \mathrm{Li} 2011$ ).

Generally, the majority of plants used for environmental restoration are typical glycophyte species. Nevertheless, metal phytoremediation by halophytes plants receives only little attention. Recently, it has been reported that halophytes species would be better adapted to cope up with environmental constraints, including heavy metals (Ghanya et al. 2007). A great deal of recent studies strongly indicates that halophytic plants could be more suitable for heavy metal extraction mainly from saline soils than glycophytes (Milic et al. 2012). The objective of the present study is to analyse the influence of different concentrations of tannery effluent on Ipomoea pes-caprae and Clerodendron inerme to characterize the morphological parameters for phytoremediation of tannery effluent contaminated soils.

\section{MATERIALS AND METHODS}

Ipomoea pes-caprae and Clerodendron inerme seedlings were collected from salt marsh area of Pichavaram, Cuddalore district, Tamilnadu, India. The seedlings were selected for the characterization and screening for phytoremediation of heavy metals and salts from tannery effluents with special reference to morphological studies. The experimental site was located at Annamalai University, Tamil Nadu, India.

\section{Experimental Design}

The experiment was conducted in an open air area with natural light, temperature and humidity. Red soil and sand (3:1 ratio) free from pebbles and stones was filled in polythene bags.

The seedlings from the selected species of similar size were transplanted from the nursery bed and planted at the polythene bags. Two experiments comprised of the three 
sets of treatments with five replicates were conducted and the average values were reported. Plants were watered every 2-3 days once, depending on the evaporative demand. The plants were harvested at intervals of 30, 60, 90 and 120 days after the treatment for further study. Physical and chemical characteristics of the tannery effluent soil were determined before planting and harvesting of halophytes. The control plants were treated without the effluent with only tap water. The various concentrations of 30,60 and $90 \%$ of the tannery effluent was prepared and treated with $250 \mathrm{~mL}$ for 4 times with a gap of 7 days interval. During each and every sampling day, samples were collected, washed thoroughly with tap water followed by distilled water. The shoot length, root length $\left(\mathrm{cm} \mathrm{plant}^{-1}\right)$, fresh and dry weight $\left(\mathrm{g} \mathrm{plant}^{-1}\right)$ number of leaves and total leaf area $\left(\mathrm{cm}^{2}\right.$ plant $\left.^{-1}\right)$ were calculated at monthly intervals. Five samples were collected from each concentration and used for studying the morphological characteristics.

\section{Shoot Length and Root Length}

The plant height was recorded by measuring the height of the plant from the surface of the soil to the tip of the plant. Root length was recorded by measuring the length of the surface soil to the tip of the root. This was recorded on 30, 60, 90 and 120 days after the treatment and expressed in $\mathrm{cm} \mathrm{plant}^{-1}$.

\section{Fresh and Dry Weight}

For the estimation of fresh weight of the leaf, stem and root portions were separated and weighed. They were dried in a hot air oven at $80^{\circ} \mathrm{C}$ for 24 hours. The fresh and dry weight was taken by using an electronic balance.

\section{Total Number of Leaves}

The total number of leaves per plant was counted immediately after harvesting the plant samples.

\section{Total Leaf Area}

The leaf area was calculated by measuring the length and breadth of the leaf and multiplying it by a correlation factor derived from the method of Kalra \& Dhiman (1977).

\section{Statistical Analysis}

The experimental data were subjected statistically by the technique of analysis of the variance and standard deviation (Suedector \& Cochran 1967).

\section{RESULTS AND DISCUSSION}

In the present investigation, observations on morphological characteristics such as shoot and root length, fresh and dry weight, number of leaves and total leaf area were determined after 30, 60, 90 and 120 days of Ipomoea pes-caprae and Clerodendron inerme treated with tannery effluent. The maximum accumulation of shoot and root length of both the species increased up to $90 \%$ on all the sampling days when compared to control (Figs. 1 and 2). The maximum

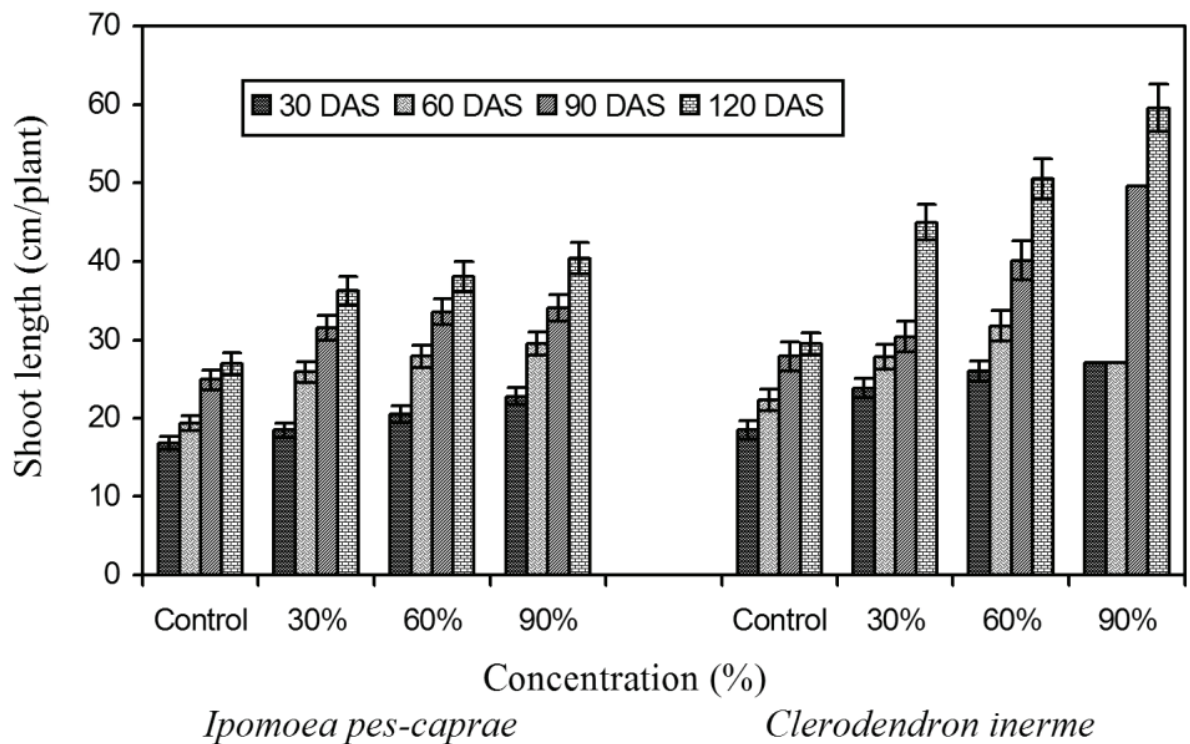

Fig. 1: Effect of different concentrations of tannery effluent on shoot length of Ipomoea pes-caprae and Clerodendron inerme. 
percentage of shoot and root length observed in Ipomoea pes-caprae (170.3\% and $142.8 \%$ ) and Clerodendron inerme (183\% and $173 \%$ ) respectively higher when compared to control of 120th days after treatment.

The fresh and dry weight of Ipomoea pes-caprae and Clerodendron inerme plants treated with tannery effluent are presented in Figs. 3 and 4. The maximum percentage of shoot and root fresh weight and dry weight observed in Ipomoea pes-caprae (283\% and 223\%) and Clerodendron inerme (427\% and $250 \%$ ) respectively were higher when compared to control on 120th day after the treatment. The similar findings were observed in the other morphological parameters such as number of leaves and total leaf area, which also increased up to $90 \%$ tannery effluent when compared

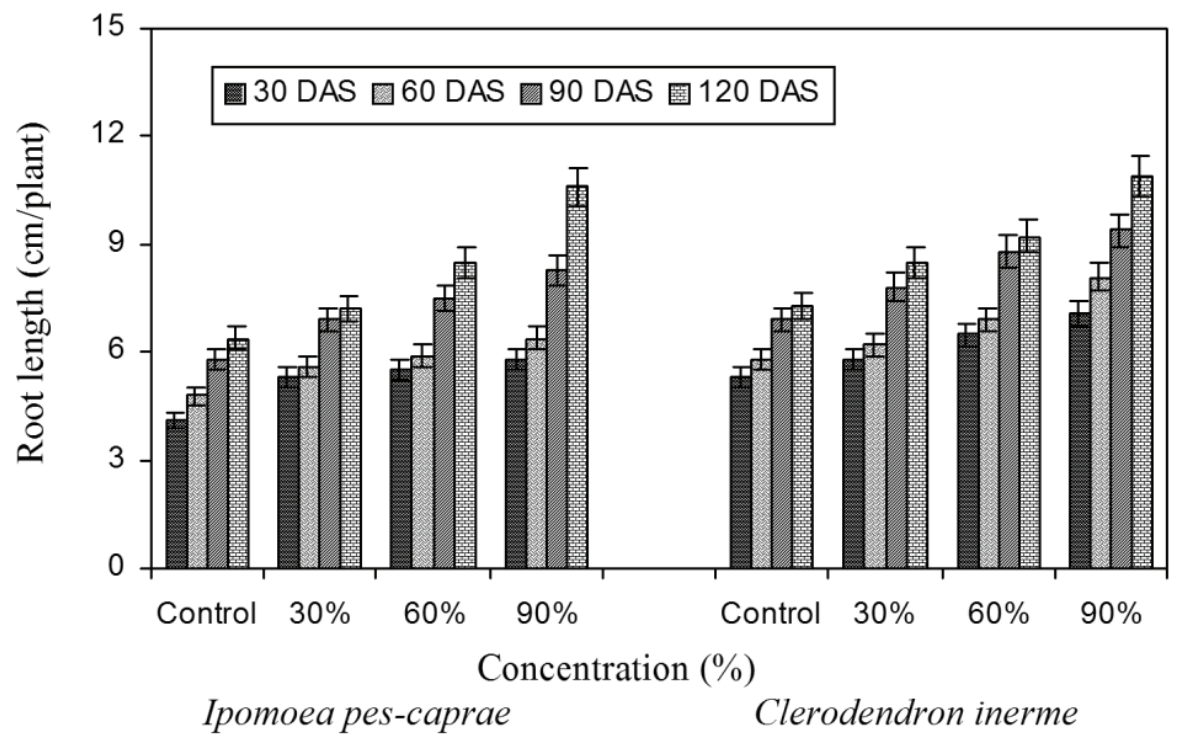

Fig. 2: Effect of different concentrations of tannery effluent on root length of Ipomoea pes-caprae and Clerodendron inerme.

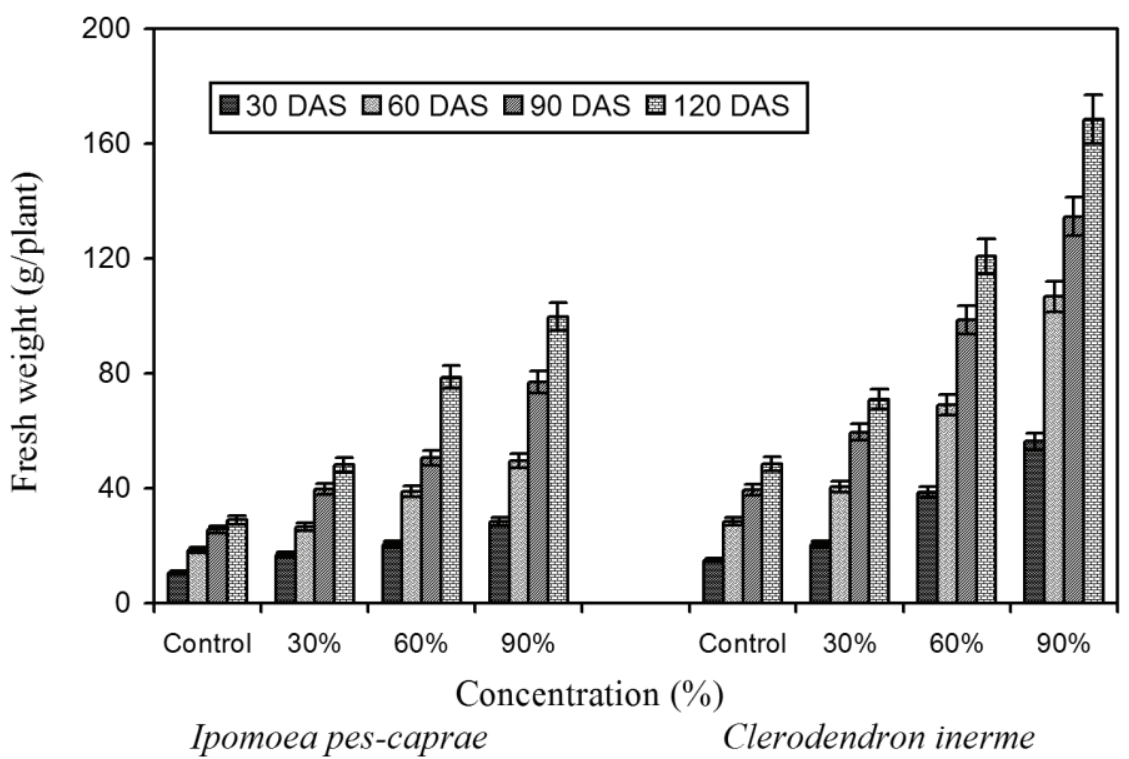

Fig. 3: Effect of different concentrations of tannery effluent fresh weight of Ipomoea pes-caprae and Clerodendron inerme. 
to control on 120 day after the treatment. The maximum percentage increased in the number of leaves $(121.05 \%$ and $443 \%)$ in Ipomoea pes-caprae and (400\% and 504\%) in Clerodendron inerme, respectively higher when compared to control on 120th day after treatment (Figs. 5 and 6).

The ability to tolerate both $\mathrm{Cd}^{2+}$ and $\mathrm{Pb}^{2+}$ accumulation in the shoot without deleterious effects on growth suggest as efficient protection of the cellular biochemical machin- ery against free metal ions $\left(\mathrm{Cd}^{2+}\right.$ and $\left.\mathrm{Pb}^{2+}\right)$ and could be of critical interest for phytomanagement of polluted areas which are frequently contaminated with several heavy metals (Eid \& Eisa 2010). The effect of artificial pollution with 25 mg.kg-1 soil of multiple $\mathrm{Zn}, \mathrm{Cu}$ and Ni on Sporobolus virginicus and Spartina petens grown for 8 weeks. They reported that no growth inhibition of shoot biomass was observed.

The reduction in fresh and dry weight due to heavy metal

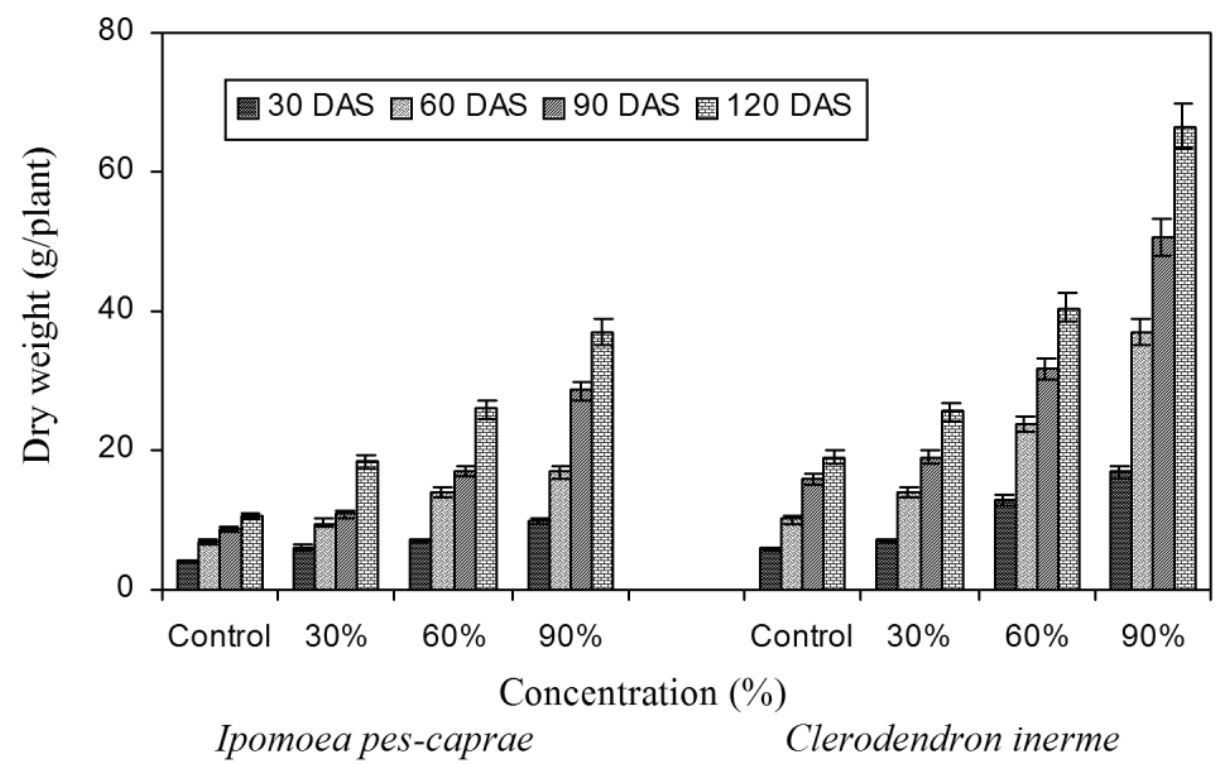

Fig. 4: Effect of different concentrations of tannery effluent dry weight of Ipomoea pes-caprae and Clerodendron inerme.

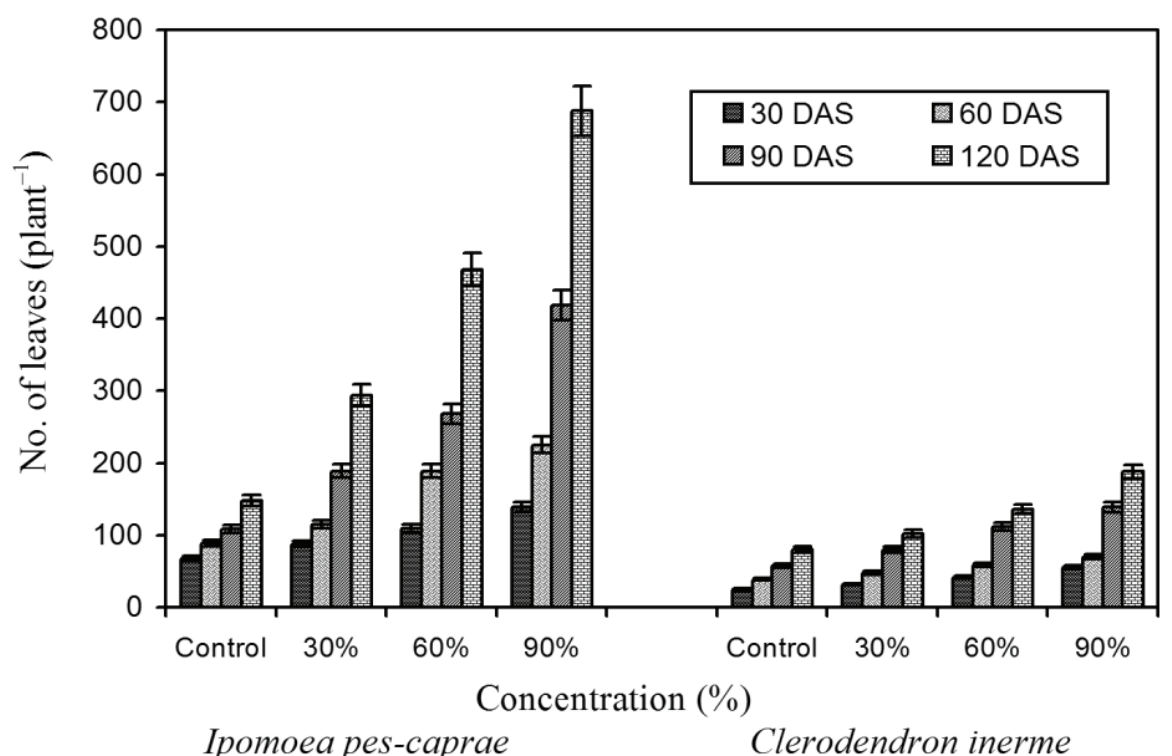

Fig. 5: Effect of different concentrations of tannery effluent total number of leaves of Ipomoea pes-caprae and Clerodendron inerme. 


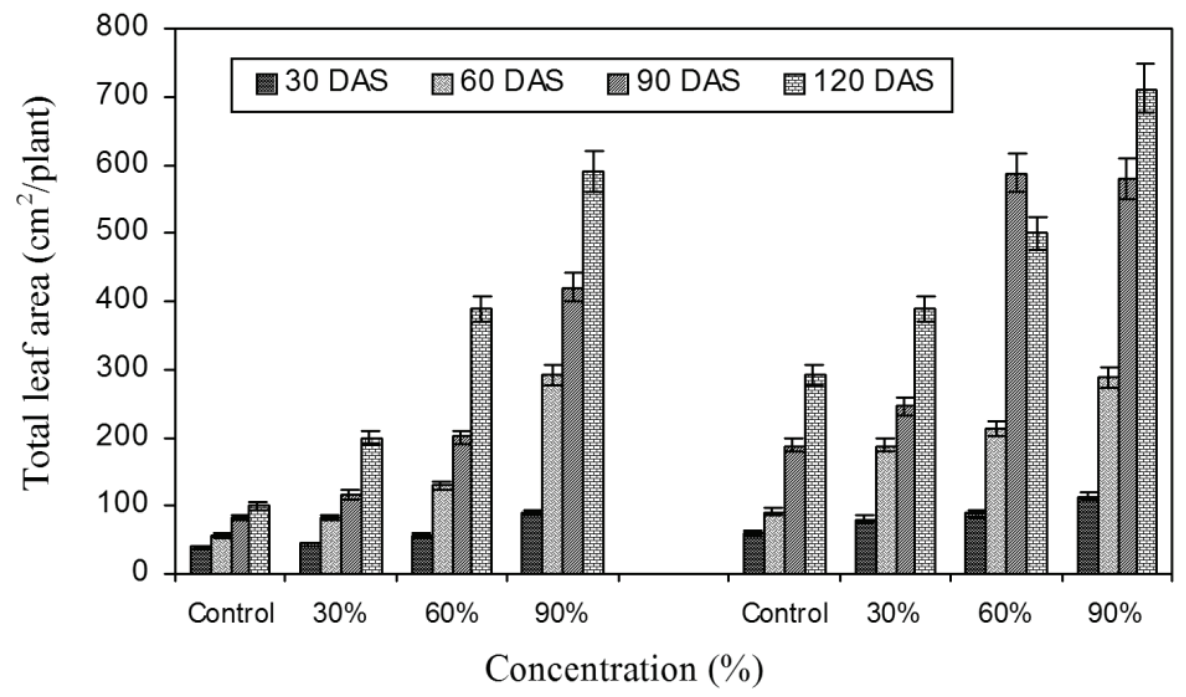

Ipomoea pes-caprae Clerodendron inerme

Fig. 6: Effect of different concentrations of tannery effluent total leaf area of Ipomoea pes-caprae and Clerodendron inerme.

treatment may be attributed to the decrease in metabolic rate and reduced transport from the cotyledons and at the same time it may also be due to the higher rate of leakage in the membrane permeability (Chitra 2017). Increase in fresh and dry weight was observed in the species of halophytes cultivated in tannery effluent treated soil. This is in accordance with the studies with several species showing that the $\mathrm{NaCl}$ stimulated the root and shoot growth of Suaeda altissima (Meychick et al. 2013) and Suaeda fruticosa (Ajmal Khan et al. 2000).

Duarte et al. (2012) identified the most abundant salt marsh halophytic species Halimione portulacoides, considered as suitable for $\mathrm{Cr}(\mathrm{VI})$ phytoremediation process by phytoextraction. The growth of Spartina alterniflora, a salt marsh halophyte was not inhibited under $\mathrm{Cu}$ stress $(50,200$, $800 \mathrm{mg} \cdot \mathrm{kg}^{-1}$ ) with no chlorotic and brown points on leaves and could be considered to be a promising candidate for phytoremedaition of copper contaminated areas (Chai et al. 2014). In the present study, the plants cultivated in tannery effluent and salt treated soil stimulated the leaf production and increased the number of leaves throughout the study period when compared to control plants. Along with increase in the leaf number there was increase in leaf area. The increase in leaf area might be due to increase in the volume of mesophyll cells with the increase in the water content of the leaves and greater accumulation of heavy metals in the mesophyll tissue with consequent increase in the leaf thickness.

\section{REFERENCES}

Ajmal Khan, M., Ungar, V. and Showalter, M. 2000. Effects of salinity on growth, water relations and ion accumulation of the subtropical perennial halophyte, Suaeda fruticosa (L.) Forsk. J. Arid Environ., 45: 73-84.

Chai, M., Shi, F., Li, R., Qiu, G., Liu, F. and Liu, L. 2014. Growth and physiological responses to copper stress in a halophyte Spartina alterniflora (Poaceae). Acta Physiol. Plant., 36: 745-754.

Chitra, K. 2017. Effect of copper on germination and seedlings growth of radish (Raphanus sativum L.). J. Environ. Sci., 11(4): 1-2.

Dixit, R., Malaviya, D., Pandiyan, K., Singh, U.B., Sahu, A., Shukla, R., Singh, B.P., Rai, J.P., Sharma, P.K. and Lade, H. 2015. Bioremediation of heavy metals from soil and aquatic environment - An overview of principles and criteria of fundamental processes. Sustainability, 7: 2189-2212.

Duarte, B., Silva, V. and Cacador, I. 2012. Hexavalent chromium reduction, uptake and oxidative biomarkers in Halimione portulacoides. Ecotoxicol. Environ. Safety, 82: 1-7.

Eid, M.A. and Eisa, S.S. 2010. The use of some halophytic plants to reduce $\mathrm{Zn}, \mathrm{Cu}$ and Ni in soil. Aus. J. Basic Appl. Sci., 4(7): 1590-1596.

Ghnaya, T., Nouairi, I., Slama, I., Messedi, D., Grignon, C., Abdelly, C. and Ghorbel, M.H. 2007. Cadmium effects on growth and mineral nutrition of two halophytes: Sesuvium portulacastrum and Mesembryanthemum crystallinum. J. Plant. Physiol., 162: 1133-1140.

Kalra, G.S. and Dhiman, S.D. 1977. Determination of leaf area of wheat plants by a rapid method. J. Ind. Bot. Soc., 56: 261-264.

Li, Y. and Li, B. 2011. Study on fungi-bacteria consortium bioremediation of petroleum contaminated mangrove sediments amended with mixed biosurfactants. Adv. Mat. Res., 183(1): 1163-1167.

Long, X.X., Yang, X.E. and Ni, E.Z. 2002. Current status and perspective on phytoremediation of heavy metals polluted soils. J. Appl. Ecol., 13: 757-762.

Manousaki, E. and Kalogerakis, N. 2011. Halophytes- An emerging trend in phytoremediation. Int. J. Phytoremed., 13(10): 959-969. 
Meychik, N.R., Nikolaeva, I.Y. and Yermakov, I.P. 2013. Physiological response of halophyte (Suaeda altissima (L.) Pall.) and glycophyte (Spinacia oleracea L.) to salinity. Am. J. Plant Sci., 4: 427-435.

Milic, D., Lukovic, J., Ninkov, J., Zeremski-Skoric, T., Zoric, L., Vasin, J. and Milic, S. 2012. Heavy metal content in halophytic plants from inland and maritima saline areas. Cent. Eur. J. Biol., 7: 307-317.
Perpetuo, E.A., Souza, C.B. and Nascimento, C.A.O. 2011. Engineering Bacteria Bioremediation. CEPEMA, Univeristy of Sao Paulo, Brazil, ISBN: 978-953-307-268-5, p. 646.

Suedector, G.W. and Cochran, W.G. 1967. Statistical Methods. Iowa State University Press, Ames, IA 